\title{
Kiss Júlia: A szerkezetváltó gimnáziumok hozzáadott tanulmányi értékének vizsgálata a családitőke-elmélet fogalmi keretei közt ${ }^{12}$
}

\begin{abstract}
Absztrakt
A szerkezetváltó gimnáziumok a magyar oktatási rendszer ellentmondásos intézményei. Az oktatásszociológiában két fö álláspont alakult ki megítélésükre: az egyik szerint a program tehetséggondozó jelleggel a jövő intellektuális elitjének korai fejlesztését végzi; a másik szerint családi háttér alapján szelektál, így mélyíti az egyenlőtlenségeket. Dolgozatomban ez utóbbi álláspontot hipotézisként használva vizsgáltam a szerkezetváltó program és a családi töke összefüggéseit. Feltételezéseim a PISA felmérés 2015-ös hullámának adatain teszteltem. Az eredmények alapján arra a megállapításra jutottam, hogy a szerkezetváltó programok tanulmányi előnye nem választható el a családi tőkétől: a családi tőke komponensei külön-külön és együttesen is meghatározzák annak esélyét, hogy ki kerül felvételre, illetve a programban mennyire lesz sikeres.
\end{abstract}

Kulcsszavak: szerkezetváltó gimnázium, PISA, oktatási egyenlőtlenségek, kvantitatív oktatásszociológia

\begin{abstract}
Multi-year gymnasia is one of the most controversial institutions of the Hungarian education system. There are two main intellectual streams in educational sociology regarding the problem: one argues that a society's prosperity depends on the competence of its intellectual elites, and multi-year gymnasia ensures the fast and efficient development of young talents; the other claims that the program selects on the base of family background, therefore deepens inequalities. In this paper I examined the connection of family capital and test scores in the 2015 PISA survey database. I concluded that the relative score advantage of multi-year gymnasia cannot be separated form family capital, and the components of family capital all together and separately determine the chances of getting into the program.
\end{abstract}

Key words: multi-year gymnasia, PISA, educational inequalities, quantitative educational sociology

\footnotetext{
1 A tanulmány a szerző tudományos diákköri konferenciára készített anyagának továbbfejlesztett változata.

${ }^{2}$ Szeretném megköszönni konzulensemnek, Rácz Andreának a dolgozat elkészítésében nyújtott segítséget és szakmai iránymutatást.
} 
Ahhoz, hogy megérthessük, hogy egy oktatási rendszerben pontosan hol és milyen közpolitikára, beavatkozásokra, szociális munkára van szükség, a rendszernek nem csak látható, de láthatatlan mechanizmusait is figyelembe kell vennünk. Az egyik ilyen láthatatlan, a diákokat az oktatási rendszeren belül elosztó mechanizmus a diákok tőkeviszonyokra épülő megkülönböztetése. Ezen - elsősorban nem pénzbeli gazdasági tőkét jelentő - viszonyok alaposabb tanulmányozása hozzásegítheti az iskolai szociális munkát végzőket, a munka szervezésében tevékenykedő szakembereket a szerkezetváltó gimnáziumokban továbbtanuló, és még inkább, az általános iskolákban maradt diákokkal való munkához való hozzáállás formálásában. Segítséget nyújthat a rendszer egy kevésbé magától értetődő, ám annál nagyobb egyenlőtlenségeket újratermelő szegmensének a pénzbeli tőkétől független újraértelmezésében.

A nyugati társadalmak oktatási és szociális diskurzusaiban sem új keletü kérdés a diákok képességek szerinti differenciálásának dilemmája. Az oktatás hosszú időn át az elitek kiváltsága volt, ám mára már szinte egy mindenki számára evidens szakasza az ember életének. Az Európai Unióban nem lehet senkit megfosztani az oktatásban való részvétel jogától például származása, társadalmi háttere vagy éppen vagyoni helyzete okán. Ezt az ideális elképzelést azonban különböző mögöttes mechanizmusok ellehetetleníthetik. Ezek a mechanizmusok nem mindentöl függetlenül léteznek: legtöbbször bizonyos oktatáspolitikai és pedagógiai gyakorlatokra vezethetők vissza (Radó 2007). Az egyik ilyen, egyenlőtlenségeket és bizonyos szintű kirekesztést közvetetten eredményező gyakorlat a szerkezetváltó programú gimnázium. A szerkezetváltó gimnáziumok a hagyományosnak tekintett 4 osztályos helyett 6 vagy 8 évfolyamos gimnáziumi programokat hirdetnek. Narratívájuk szerint funkciójuk, hogy a tehetséges fiatalokat a lehető leghamarabb megtalálják, és képességeik legjobb fejlesztését minél hamarabb elkezdhessék. Ezt az álláspontot erősíti, hogy a szerkezetváltó gimnáziumok rendszerint magasabb eredményeket érnek el olyan standard teszteken, mint a PISA felmérés. ${ }^{3}$ A szerkezetváltó programok ellen érvelök azonban rámutatnak, hogy a gyakorlatban az ezen intézmények által megkövetelt korai szelekció nagy mértékben elmélyíti a meglévő oktatási egyenlötlenségeket (Liskó 1993; Radó 2005, 2007; Strakova 2012). Az utóbbi álláspontot képviselő szerzők leggyakrabban amellett érvelnek, hogy a szerkezetváltó programok nem valós képességek, hanem családi háttér alapján választják ki a diákjaikat. Ezen szelekció különböző negatív következményei túlmutatnak az oktatási rendszer keretén, az azáltal okozott hátrányokat egyszerre kell orvosolni családoknak, pedagógusoknak és a szociális szférának, különös tekintettel a szociális munkára.

Az az álláspont, mely szerint az iskolarendszer előnyben részesíti a jobb hátterü gyermekeket, nagy hagyománnyal és végtelen szakirodalommal rendelkezö, illetve a szociális területen tevékenykedők számára jól ismert jelenség. Dolgozatomban ezen hagyomány egy irányát, a tőkeelméleteket emelem ki. Röviden ismertetem Bourdieu és Coleman tőkeelméleteinek idevágó részeit, majd bemutatom Raymond Sin-Kwok Wong ezek alapján alkotott szintézisét. Kutatásomban azt vizsgálom, hogy a Wong-féle családitőke tipológia (1998) három tőkekomponense (anyagi, kulturális és humán) külön-külön és együttesen milyen összefüggésben van a szerkezetváltó gimnáziumok jobb tanulmányi teljesítményével. A rendelkezésre álló szakirodalom és kutatások alapján feltételezem, hogy a szerkezetváltó programok jobb teljesítménye bizonyos háttérváltozókra történő kontrollálás után lényegesen lecsökken, vagy eltünik. Feltételezéseim tesztelését a PISA mérés 2015-ös hullámának adatain végzem.

\footnotetext{
3 A 2015-ös PISA mérés adatai alapján végzett számításaimban is erre a megállapításra jutok, illetve az OEDC kimutatásai, és számos elemzés is hasonló eredményeket produkál.
} 
A családi tőke komponensekre bontása, hatásának ilyen módon való megfigyelése hozzájárulhat az iskolai egyenlőtlenségek ezen szegmensének jobb és pontosabb megértéséhez. Új perspektívát nyújthat továbbá a családi tőke komplexebb felfogásához és annak kvantitatív elemzések során való alkalmazásához. ${ }^{4}$

\section{Szelekció az oktatási rendszerben}

Az oktatási rendszer diszfunkciója a társadalom egészét befolyásoló következményekkel jár, melyek nagyban meghatározzák a jelen és a jövő munkaerőpiacának felépítését, a gazdasági folyamatokat, ahogy a társadalom mentalitására is jelentős hatással vannak. A magyar oktatási rendszer egy fontos és sokat tárgyalt ilyen diszfunkciónak tekinthető vonása, hogy nemzetközi összehasonlításban is kiugróan magas a szociális háttér hatása a diákok tanulmányi teljesítményére (OECD 2010, 2016, 2017). E hatás mellett eltörpül a lakóhely, a nem, vagy a korlátozott személyes képességek hatása (Radó 2007, 2018). Az, hogy az iskola képes-e ellensúlyozni a családi háttér hatását, széleskörüen vizsgált és vitatott kérdés. A probléma okai és magyarázatai egyrészt pedagógiai, másrészt rendszer-és társadalmi szintü mechanizmusokban keresendők. Jelen dolgozatban nincs lehetőség a probléma minden részletre kitérő tárgyalására, így csak az elemzésem szempontjából leginkább releváns részét, a szelekciós folyamatot mutatom be, illetve annak is csak bizonyos aspektusait.

Azt a feltételezést, hogy Magyarországon a tanulók családi háttere nemzetközi összehasonlításban is kiugróan nagy hatást gyakorol az iskolai teljesítményre, olyan nagy, komparatív felmérések is alátámasztják, mint a PISA mérés (Csapó-Molnár-Kinyó 2009) Kevésbé alapvetésként kezelt tény azonban - ahogy Radó Péter 2018-as tanulmányában rávilágít -hogy a hatás a hazai iskolarendszer szelektivitása miatt nem közvetlenül, sokkal inkább az iskola státuszán ${ }^{5}$ keresztül történik (Radó 2018).

A szelekciót az eltérő hátterű diákok különböző intézménytípusokban különböző szintü részvételeként definiálhatjuk. ${ }^{6}$ (Radó 2018) Ez a jelenség az oktatási rendszer minden szinten erős differenciáltsága miatt Magyarországon jól megfigyelhető, intézményesült, de nem szabályozott ${ }^{7}$ gyakorlat. Ez nem csak azért jelent problémát, mert tér nyílik például olyan folyamatoknak, mint az etnikai szegregáció, hanem azért is, mert a különböző iskolák különböző ,„pedagógiai minőséget” képviselnek, és különböző erőforrásokhoz férnek hozzá. Így törvényszerűen, a jobb hátterű gyerekek kerülnek az erőforrásokkal jobban ellátott iskolákba, míg inkább rászoruló társaik a hátrányosabb helyzetü intézményekbe szorulnak.

Fontos megjegyezni, hogy a szelektív oktatási rendszert nem az jellemzi, hogy van szelekció a különböző szintek és képzési típusok belépési pontjainál, hiszen ez minden rendszer jellemzője. Nincs olyan oktatási rendszer, ahol a kapacitások és igények közt teljes a megfelelés. Radó Péter 2007-es definíciója szerint: "...(Egy oktatási rendszert szelektívnek tekintünk)...ha a

\footnotetext{
${ }^{4}$ Wong szerint a családi háttér mérésére gyakran csak az apa iskolai végzettségét használják, mely meglátása szerint nem elégséges és nem nyújt elég tiszta képet

${ }^{5}$ A tanulmányban a tanulói ESCS-indexek iskolai szintű aggregációja állítja elő az iskolák státuszindexét.

${ }^{6}$ A szelektivitás ennél lényegesen tágabb fogalom, magában foglalja mindazokat a rejtett vagy intézményesült folyamatokat, amelyek a szelekciót okozzák. (Radó 2018) Dolgozatomban elöbbire koncentrálok
}

${ }^{7}$ Az oktatási rendszer alap- és középszinten is nagyon sok elágazási utat ad, ami magas szelektivitáshoz vezet (ami etnikai szegregációt eredményez, mely törvényileg tiltott, de a szelekció miatt gyakori jelenség). (Radó 2018). 
szelekció - mint Magyarországon is - igazságtalan, szinte kizárólag a tanulók társadalmi háttere által meghatározott módon zajlik. ”(Radó 2007).

A szelekció problémájával kapcsolatban a nemzetközi és hazai szakmai diskurzusban sincs egységes álláspont. Ennek egyik oka, hogy az oktatási rendszer funkcióját többféleképpen értelmezhetjük. Itt csak két nagy, releváns irányt említek meg, amelyek a szelektív rendszerek megítélése szempontjából különösen fontosak: (1) az iskola feladata a diákok közös szocializációját biztosítsa; vagy (2) hogy „különböző jövőket” biztosítson, és ennek érdekében differenciálja a diákokat (Gamoran 2009:3). Az utóbbi álláspontot képviselő szerzők amellett érvelnek, hogy az iskolai pályák differenciálása és az éles szelekció elengedhetetlen és kívánatos jelenség, amely az adott társadalom jövőbeli intellektuális elitjének megfelelő minőségü képzését biztosítja. Ebbe a táborba sorolható például Kulik (1992) is. Érvelése szerint a tény, hogy a tehetséges diákok tanulmányi szempontból profitálnak a differenciált oktatásból, számára legitimálja a szelektivitás létezését. Másik példa lehet Loveless (1998), az ő érvelése szerint az iskoláknak meg kell hagyni a differenciálás jogát, nem kívánatos központilag szabályozni azt.

A differenciálás jelen formája ellen érvelők táborába sorolható egyaránt Slavin $(1987,1990)$ Kerckhoff (1986) és Radó (2007, 2018). Slavin kiemeli, hogy a csoportokba sorolás önmagában semmilyen hatással nem jár, a negatív hatások akkor jelennek meg, ha a csoportoknak különbözik a tananyaga, anyagi és pedagógusi erőforrásokkal jobban ellátottak. Radó nagyon hasonló következtetésre jut: a szelekció akkor válik negatívvá, ha mechanizmusai a családi háttér alapján szisztematikusan válogatnak; illetve, ha az így kialakult csoportok más ellátottsággal rendelkeznek (Radó 2007). Mind a ketten azzal az előfeltevéssel élve érvelnek a (túlzott) szelekció vagy tagozatosodás ellen, hogy a társadalom nem képes a differenciálást a negatív vonások nélkül megvalósítani. Az empirikus kutatások nagyrészt a gyakorlat ellen érvelők állításait támasztják alá (Straková 2014).

\section{A szerkezetváltó gimnáziumok}

A szerkezetváltó gimnáziumok hazánkban jelenlegi formájukban pár évtizedes múltra tekintenek vissza. Bár a 8 osztályos gimnáziumok nagy hagyománnyal rendelkeznek, a rendszerváltás előtt a gimnáziumok egységesen 4 éves képzési formában müködtek. Az 1985. évi közoktatási törvény szerint a gimnáziumok 4 osztályosak voltak, ám külön minisztériumi engedéllyel volt lehetőség szerkezetváltásra (Badó-Józsa 2017). Az 1990-es években a 6 és 8 osztályos gimnáziumok már aránylag elterjedtek voltak: míg az 1989/90-es tanév előtt 0, ebben az évben 2 szerkezetváltó program indult, az 1993/94-es tanévben már összesen (6 és 8 évfolyamos programból) 169 program indult el (Balogh 2001). Erre reagálva az 1993-ban hatályba lépett oktatási törvény alapján a szerkezetváltó program indítása törvényileg megengedett és külön engedélyhez nem kötött ${ }^{8}$ lehetöség volt, a 28. § (2) bekezdése szerint ugyanis "a gimnázium a nevelést és oktatást az ötödik, a hetedik vagy a kilencedik évfolyamon kezdi". Ez lehetővé tette, hogy ez az oktatási forma szélesebb körben is elterjedhessen (Balogh 2001).

A szerkezetváltó gimnáziumok deklarált célja az elitképzés, „értelmiségivé nevelés” volt (Balogh 1991). Ennek érdekében szigorú felvételi vizsga alapján szelektálták a „legjobb képességü" tanulókat. Legitimációjuk nagy mértékben ma is erre a célkitüzésre és az ebből következő feltevésekre épül: A társadalom jövőbeli jóléte attól függ, hogy az mennyire effektíven tudja felkészíteni és kompetenssé tenni vezető intellektuális elitjét; A

8 Bármely korábban jóváhagyott program használatával lehetett szerkezetváltó osztályt indítani (Badó-Józsa 2017) 
„tehetséggondozás” haszna nagyobb, mint az így alul maradottak vesztesége (Strakova 2014). A szerkezetváltó gimnáziumok narratívája a mai napig ezt a legitimációs alapot sugallja.

Az iskolai szelekció két formáját különíthetjük el: a látens és intézményesült gyakorlatokat: Előbbi abból adódik, hogy a tájékozottabb, jobb érdekérvényesítő képességü szülők jobbnak ítélt iskolákba viszik gyerekeiket; utóbbi pedig egy tudatos, képességeken alapuló - vagy erre hivatkozva legitimált - szelekció, mely általában felvételi vizsgát jelent. (Csapó 2003). A szerkezetváltó gimnáziumok esetében természetesen a látens folyamatokról nem áll rendelkezésünkre semmilyen jó minőségü adatforrás, amíg az intézményesült szelekció pontosan az intézményesült jellegénél fogva - központilag dokumentált. Ugyanakkor a látens folyamatok végeredményeként létrejövő differenciálódásra következtethetünk a tágabb fókuszú oktatásszociológiai kutatások eredményeiből.

Jana Strakova (2014) kutatásában a cseh oktatási rendszer korai szelekciós gyakorlatait vizsgálta különös tekintettel a többéves gimnáziumokra. A kutatás eredményeit érdemes a magyar rendszerre vonatkozóan is figyelembe venni. Eredményei azt mutatják, hogy (1) diákok átlagos vagy átlag alatti eredménnyel törekszenek a többéves gimnáziumokba, míg sok, eredményeik alapján „tehetségesebb” diák nem törekszik erre (alapfokon); (2) a többéves gimnázium nem járul hozzá a diákok alapkészségeinek fejlődéséhez jobban, mint a hagyományos, általános iskola + négy évfolyamos gimnáziumi osztályos rendszer.

Ezek alapján felmerül a kérdés, hogy ha a többéves gimnáziumokban nem a képességek vagy „,kiválóság” alapján szelektál a felvételi folyamat, és nem a képességeik alapján legjobb diákok kerülnek ezekbe a programokba, akkor milyen tulajdonságok játszhatnak döntő szerepet a felvételi folyamat során?

\section{Tőke és oktatás}

A tőke különböző értelmezéseinek, megjelenéseinek és formáinak társadalomtudományi irodalma rendkívül tág és szerteágazó. A fogalom definiálása ebből következően meglehetősen nehéz. Nincs ez máshogy az iskolai eredményességet vizsgáló kutatások esetében sem, ahol a konkrét vizsgált témától függően a kutatók különböző aspektusokra koncentrálnak attól függően, hogy milyen konkrét kérdést vizsgálnak (Pusztai 2009)

Az alábbiakban a jelen kutatás szempontjából legrelevánsabb szerzőket és definíciókat mutatom be, a témával foglalkozó teljes szakirodalom ismertetésének igénye nélkül.

Pierre Bourdieu a tőkeelméletek talán legismertebb képviselője a XX.század második felében, az ő munkássága köti össze a klasszikus tőkefelfogást a kortárs társadalomtudományi szemlélettel. Tőkeelmélete (1986) magába foglalja a tőkék minden területre kiterjedő értelmezését, túllép a kizárólagos gazdasági és anyagi fókuszon. Kategorizációja szerint a tőke három fő formája a gazdasági-, a kulturális- és a társadalmi tőke. Ebből komplex, a társadalmi osztályok hatalmi mechanizmusait leíró elméletet formál. Érvelése szerint a tökeelmélet alkalmas tehát arra, hogy a társadalmi egyenlőtlenségek meghatározó részét megmagyarázza.

Definíciója szerint a tőke felhalmozott, akkumulált munka, melynek alapvető tulajdonsága, hogy képes reprodukálni magát és profitot termelni; elsajátításához időre van szükség; ám a többi egyénnel szemben előnyt biztosít birtoklójának (értéke ebben rejlik).

A tőkefajták más tőketípusokba konvertálhatók; azonban minden tőke alapja bizonyos mértékben a gazdasági tőke. A három töketípus összefonódik egymással, sok esetben egyik birtoklása a másikból következik. Bourdieu tanulmányaiban sokat foglalkozik a tőkével leírható egyenlötlenségeket talán legjobban szimbolizáló iskolai egyenlőtlenségekkel. Jelen dolgozat 
szempontjából leginkább releváns írása Az iskolai kiválóság és a francia oktatási rendszer értékei (Bourdieu 1978). Ezen müvében rámutat többek közt arra, hogy a francia oktatási rendszer olyan (elitista) elvárásokat támaszt diákjaival szemben, melyeket csak a megfelelő tőkével rendelkező egyének tudnak sikeresen teljesíteni. Ennek következtében, a francia oktatási rendszer nem objektíve, a diákok valós képességei alapján ad lehetőséget előrehaladásra, sokkal inkább adott tőketípusok birtoklásának függvényében. Bourdieu rávilágít, hogy az iskolai sikerességre legközvetlenebb hatással lévő tőketípus a kulturális tőke (Bourdieu 1999).

Bourdieu rendszerezése a töke hatásának holisztikus megragadására törekedett, azonban kritikusai szerint van egy hatalmas hiányossága, a társadalmi tőke pontos operacionalizálása. Bourdieu a társadalmi tőkét az ,aktuális és potenciális erőforrások összege (...) kölcsönös ismeretségek vagy elismerés többé-kevésbé intézményesült viszonyai tartós hálózatának birtoklása"-ként definiálja (Bourdieu 1999), így elméleteiből hiányzik a tőketípus jól meghatározott mérhetőségének lehetősége. Ezt a hiányosságot több szerző próbálta orvosolni, közülük Coleman elméletét mutatom be részletesen.

Coleman tőkeelméletekkel foglalkozó tanulmányaiban alapvetően a társadalmi tőke formáival és megjelenéseivel foglalkozik. 1988-as müvében (Coleman 1988) a középiskolai lemorzsolódás példáján keresztül mutatja be a társadalmi tőke természetének főbb vonásait. Elmélete szerint a társadalmi tôke pontos leírásához figyelembe kell venni a társadalmi cselekvés értelmezésének két fő intellektuális irányát. Az inkább szociológusok által üdvözölt társadalmi kontextusra fókuszáló elképzelést, mely szerint az egyén a normák, szabályok, kötelességek és struktúrák hatására cselekszik. A második a közgazdaságtan kedvelt narratívája, mely az egyént, mint cselekvőképes, független célokkal rendelkező lényt látja, akinek cselekvését a hasznosság maximalizálása irányítja. Coleman tehát a két irányzat ötvözésében látja a társadalmi tőke meghatározásának módját.

Coleman szerint míg az anyagi/fizikai töke termelési eszközökben; a humán tőke pedig az egyénekben létrejövő új képességekben rejlik; addig a társadalmi tőke az egyének közti kapcsolatokban keresendő. A társadalmi töke fontos jellemzője, hogy-más tőkékhez hasonlóan - generációról generációra öröklődhet, így teret adva az elönyös és hátrányos helyzetek generációkon keresztüli tovább élésének (intergeneration conversion theory).

Coleman intergenerációs elméletét több kutató is megpróbálta kiegészíteni. Ezek közül Wong 1998-as tanulmányában egy az intergenerációs egyenlőtlenségek jobb leírására képes módszer bevezetését kísérli meg (Wong 1988). A szerző Coleman intergenerációs konverziós folyamat teóriáját, Bourdieu kulturális tőke elméletét (cultural capital theory), és a társadalmi hálózatok elméletét (social network theory) ötvözve azonosította a családi tőke (family capital) 4 olyan komponensét, melyek véleménye szerint a legpontosabban képesek magyarázni a diákok iskolai eredményességét vagy annak ellenkezőjét. Meglátása szerint ezen tőkék alapos elkülönítésével és operacionalizálásval jobban megragadható az egyenlötlenségek problémaköre, mint a témában folytatott empirikus kutatások nagyrésze által tradicionálisan használt változók használatával (Wong 1998).

Wong a családitőke-elméletbe bevonja az anyagi és humántőke mellé a kulturális és társadalmi tőkét is. Ezeket a komponenseket az előbbi két szerző is azonosította, ám ilyen pontosan operacionalizált formában nem illesztették őket össze.

Wong a családi tőke komponenseit szükebben a következőképpen definiálja:

1. Humán tőke: megtestesíti a potenciált egy olyan kognitív környezetre, mely segíti a gyermek tanulását; 
2. Anyagi tőke: olyan fizikai erőforrások, melyek potenciálisan segítik a teljesítményt;

3. Társadalmi töke: olyan kapcsolatok a szülök, a gyermekek és közösségi szervezetek közt, melyek segíthetik a gyermek (vagy később fiatal felnőtt) kognitív vagy szociális fejlődését, előrejutását

4. Kulturális tőke: megtestesíti az otthoni környezet, illetve a szülők és gyermekek által együtt töltött idő minőségét (Wong 1998:4)

Wong érvelését figyelembe véve elemzésem során az általa javasolt 4 családitőkeforma használatával írom le a családi háttér hatását a vizsgált kérdéskörben. Az elméletet különösen jó értelmezési keretnek tartom témám vizsgálatához, hiszen célom, hogy a családi háttér komplex hatását komponensekre bontva tudjam vizsgálni a szerkezetváltó és a tradicionális képzési programok összehasonlítása során.

\section{Kutatási kérdés, metodológia}

Az előző fejezetekből látható, hogy a közvélekedésben a szerkezetváltó gimnáziumok a tehetséges diákok képességeinek legeffektíveb fejlesztési módjai, ugyanakkor az empirikus kutatások afelé mutatnak, hogy ezek az intézmények nem tisztán kompetencia alapon választják ki diákjaikat, elmélyítve ezzel a társadalmi egyenlőtlenségeket.

Kutatásomban azt vizsgálom, hogy a PISA felmérés 2015-ös hullámának adatai alapján a szerkezetváltó gimnázium tanulmányi elönye ${ }^{9}$ akkor is kimutatható-e, ha a családi töke komponenseire ${ }^{10}$ kontrollálunk?

A fentebb bemutatott szakirodalom alapján a feltételezéseim a következők:

Hipotézis 1: a családi tőke komponenseinek eloszlása hagyományos és szerkezetváltó programok közt egyenlötlen, a szerkezetváltó programok előnyére.

Hipotézis 2: ha a családi tőke komponenseire kontrollálunk, a szerkezetváltó programok pontszámbeli előnye lecsökken vagy megszünik.

\section{Adat bemutatása}

A töke és iskolai eredményesség összefüggéseivel foglalkozó kutatások esetében a fókusz két fó irány szerint alakul: az eredményesség oktatáspolitikai alapon való mérése (pl.: beavatkozások/beruházások haszna) és az eredményesség oktatásszociológiai meghatározása (pl. mobilitási lehetőségek). A két megközelítés különbözősége ellenére vannak olyan mutatók, melyek elméletben képesek mindkettőt mérni. Ilyenek például a kompetenciateszt-eredmények (Pusztai 2009). Elemzésemben így az egyik legfontosabb kompetenciateszt, a PISA felmérés adatbázisát használom. A PISA felmérés használata mellett szól az is, hogy a kompetenciateszt eredményei mellett, jól operacionalizált háttérváltozókat is tartalmaz az általam vizsgált aspektusokról is.

\footnotetext{
9 A PISA 2015 adatok alapján pontszámbeli előnye

10 Családi tőke alatt a Wong-féle családitőke tipológia 3 komponensét értem (anyagi-, kulturális-, humán tőke)
} 
A PISA ${ }^{11}$ mérés 3 évente ismétlődő hullámokban zajlik, és kizárólag 15 éves diákokat kérdeznek benne. Magyarországon ez 7-10. osztályos diákokat jelent. Elemzésemben csak a 810. osztályokat vizsgálom, hiszen bár a felmérés reprezentatív, a 7.osztályban túl alacsonynak ítélem az elemszámot ahhoz, hogy azt statisztikai elemzésembe bevonjam. Ugyanez a kritika érheti a 8. osztályok elemszámait is, de ennek az évfolyamnak a bevonása szükséges ahhoz, hogy az általános iskolákat is összevethessem a szerkezetváltókkal, amely, mint az elemzés során látható, különösen tanulságos (1. Ábra). A 2015-ös vizsgálatban 72 országból 540000 tanuló vett részt, reprezentálva az országok 29 millió 15 éves tanulóját. Magyarországról ebben az évben 5659 tanuló került a mintába.

1. táblázat: A minta elemszámai osztályra és iskolára bontva

\begin{tabular}{|l|c|c|}
\hline Iskolatípus & Évfolyam & Elemszám \\
\hline Általános iskola & 7. & 31 \\
\hline Általános iskola & 8. & 166 \\
\hline 4 osztályos gimnázium & 8. & 1 \\
\hline 4 osztályos gimnázium & 9. & 1522 \\
\hline 4 osztályos gimnázium & 10. & 300 \\
\hline 6 osztályos gimnázium & 7. & 1 \\
\hline 6 osztályos gimnázium & 8. & 10 \\
\hline 6 osztályos gimnázium & 9. & 258 \\
\hline 6 osztályos gimnázium & 10. & 49 \\
\hline 8 osztályos gimnázium & 8. & 12 \\
\hline 8 osztályos gimnázium & 9. & 149 \\
\hline 8 osztályos gimnázium & 10. & 42 \\
\hline Szakgimnázium & 9. & 1655 \\
\hline Szakgimnázium & 10. & 328 \\
\hline Szakközépiskola & 9. & 700 \\
\hline Szakközépiskola & 10. & 121 \\
\hline Összesen: & & $5.345^{12}$ \\
\hline
\end{tabular}

11 PISA (Programme for International Student Assessment-Nemzetközi Tanulói Teljesítménymérés Program) az OECD (Organisation for Economic Co-operation and Development-Gazdasági Együttmüködési és Fejlesztési Szervezet) nemzetközi szervezet által fenntartott felmérés, mely az 1990-es évek óta számos országban a 15 éves tanulók háttérére és (kompetencia alapú) teljesítményére vonatkozó adatokat gyüjt

12 Az Oktatási Hivatal jelentése szerint 2015-ben 5659 diák képviselte Magyarországot, ugyanakkor, ahogy a fenti táblázatból látható a PISA nyers adatbázisban 5345 diákról szerepelnek megfigyelések 
A nemzetközi komparatív oktatásfelmérések survey designjai a nemzetközi összehasonlíthatóság érdekében úgy lettek kialakítva, hogy a diákok teljesítményét standardizálva, nemzeti és nemzetközi szinten összevethető módon mérjék. Ilyen nagy nemzetközi mérés a TIMSS, a PIRLS, és a PISA is. Az összevethetőség jegyében egy olyan komplex survey-designnal készülnek, mely hatással van a mérés módjára, az alkalmazott mintavételre és a súlyozásra is. A felmérés mintavétele két lépcsős. Az első lépésben az iskolák közül választanak, úgy, hogy az ország összes releváns iskolatípusából érkezzen információ, így a szerkezetváltó gimnáziumokból is. A második lépcsőben a kiválasztott diákok rotált kérdőíveket töltenek ki, amelyek tartalma nem egyezik meg teljesen, de a PISA által alkalmazott lehetséges értékek módszere szerint összehasonlítható. A komplex mintavétel miatt az alkalmas elemzési eszközök száma alacsony ${ }^{13}$, a saját vizsgálataimat az intsvy nevú $\mathrm{R}^{14}$ csomaggal végeztem.

\section{Módszerek bemutatása}

Elemzésem első felében (frekvenciatáblák és átlagvizsgálatok segítségével) a családi tőke komponenseire vonatkozó változók és a teljesítmények alakulását vizsgáltam osztályokra és iskolatípusokra bontva.

Ezután az elemzés első felének tanúságai alapján regressziós modelleket építettem. Az egymást követő modellekbe graduálisan vontam be a magyarázó változókat, míg elértem egy végsőnek tekintett modellt, melyben a családi tőke összes komponense, és több, a diákokra vagy az iskolákra vonatkozó háttérváltozó is szerepelt.

\footnotetext{
${ }^{13}$ A több dimenzióban is komplex adatstruktúrát az egyszerübb statisztikai programok nem tudják kezelni, speciális programokra van szükség elemzésükhöz (Pl.: IDB analizer). Az OECD minden PISA hullámhoz kiad olyan SPSS makrókat, melyek lehetővé teszik az ebben a programban való elemzést. A 2015-ös hullámhoz (feltehetőleg a lehetséges értértékek számának megváltozása következtében) ilyenek nem készültek. Ha az adat komplex természetét nem vesszük figyelembe, a becslések tévesek lesznek.

Megoldást jelent erre egy szabadon felhasználható R-csomag, az instvy package, mely a PISA adatok kezelésére lett kifejlesztve.

${ }^{14}$ Elemzéshez használt útmutató: Caro, D. H., \& Biecek, P. (2017). Intsvy: An R package for analyzing international large-scale assessment data. Journal of Statistical Software, 81(7), 1-44.
} 
A Wong-féle három ${ }^{15}$ családitőke-komponens definiálása elemzésemben a következőképpen alakul:

1. Humán tőke: szülők iskolai végzettségének foka és típusa (HISCED ${ }^{16}$ skála 3 kategóriába kódolva).

2. Anyagi tőke: adott, a család által birtokolt ingóságok (WEALTH index ${ }^{17}$ )

3. kulturális töke: adott kulturális tevékenységek és színterek látogatása (CULTPOSS index ${ }^{18}$ )

Fontos megjegyezni, hogy kvantitatív adatfelvételekben olyan változókat nem lehet találni, melyek tökéletesen megfeleltethetőek lennének egy-egy komponensnek. Ugyanakkor azt gondolom, hogy mindegyik választott változó jó proxy, amelyek használatával ha nem is tökéletesen, de ki lehet mutatni, hogy Wong elméletével releváns-e és érdemes-e magyarázni a szelekciós folyamatot.

\section{Elemzés eredményei}

Frekvencia és átlagvizsgálatok:

Az átlag matematika és olvasás pontokról elmondható, hogy a szerkezetváltó programok diákjai 8., 9. és 10. osztályban is magasabb pontokat értek el átlagban, mint a más programokban tanulók. Fontos azonban megjegyezni, hogy a különbség csak az általános iskolákkal szemben különösen magas. A 4 évfolyamos gimnázium átlagpontszámai sokkal közelebb vannak a szerkezetváltó programokéhoz. A három gimnáziumtípus közti különbség tehát konstans, de nem túl nagy előnyt jelent a 6 és a 8 évfolyamos diákok részére.

1. ábra: Matematika pontszámok átlagai iskolatípusra és osztályra bontva $(\mathbf{N}=\mathbf{2 0 5 8})$

\begin{tabular}{|l|c|c|c|}
\hline \multicolumn{4}{|c|}{ Matematika pontszám átlaga osztályra és iskolatípusra bontva } \\
\hline Iskolatípus & 8. osztály & 9. osztály & 10. osztály \\
\hline $\begin{array}{l}\text { Általános iskola, } 4 \\
\text { osztályos gimnázium }\end{array}$ & 395,59 & 524,93 & 524,93 \\
\hline 6 osztályos gimnázium & 513,21 & 542,86 & 542,86 \\
\hline 8 osztályos gimnázium & 568,97 & 561,75 & 561,75 \\
\hline
\end{tabular}

\footnotetext{
15 Ahogy ezt az előzőekben jeleztem, Wong 4 komponenst határoz meg cikkében, azonban a 4., társadalmi tőke komponens nem mérhető a PISA adatbázis alapján, ezért elemzésemben 3 komponenst vizsgálok.

16 A PISA adatbázisban eredetileg is szereplő, a szülők iskolai végzettségének összegét mérő változót 3 kategóriára szükítettem: alapfokú végzettség, középfokú végzettség és felsőfokú végzettség. Az értékek a 2 szülő végzettségének átlagát jelentik.

17 A PISA adatbázisban eredetileg is szereplő anyagi javakat mérő index (eredeti formájában használtam)

18 A PISA adatbázisban eredetileg is szereplő, kulturális tőkét mérő index (eredeti formájában használtam)
} 
A Wong-féle családitőke-elmélet humán komponense alapján viszonylag nagy különbségek figyelhetők meg iskolatípusonként.

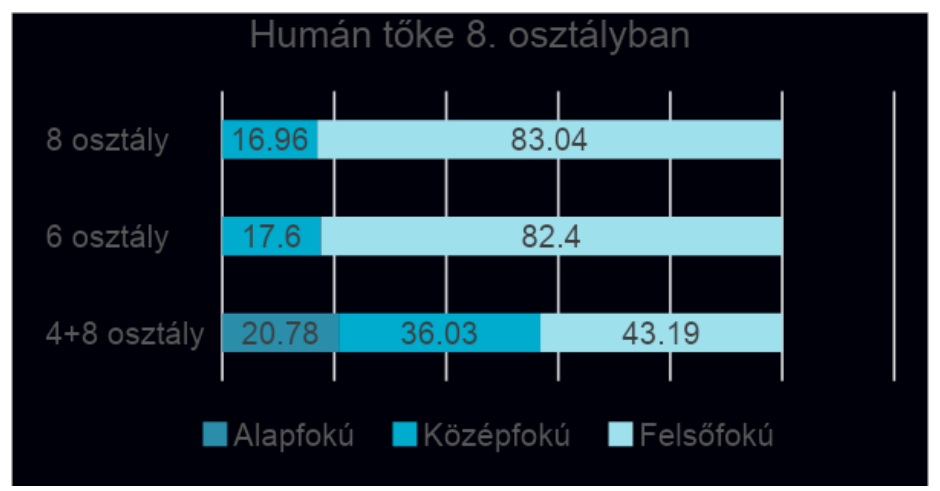

A

szerkezetváltó

gimnáziumok három vizsgált osztályának mindegyikében $0 \%$ az alapfokú végzettségű szülő, mindenhol jelen van egy nem túl nagyarányú középfokú végzettségű populáció, és mindenhol a felsőfokú végzettség domináns. A 4 évfolyamos gimnáziumokban ezzel szemben jellemző kiegyenlítettebb a középfokú és felsőfokú végzettségüek aránya (szintén a felsőfokú a domináns), emellett azonban megjelenik egy rendkívül alacsony, alapfokú végzettséggel rendelkező réteg is.
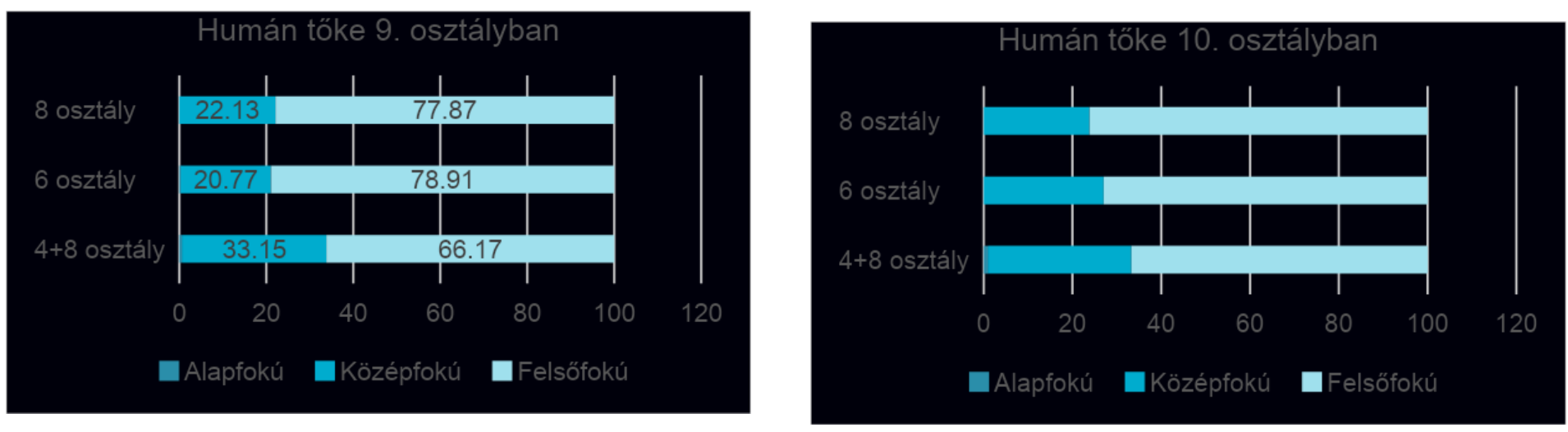

A második, anyagitőke-komponens érdekes eredményeket mutat: bár van egy gyenge tendencia, amely szerint minden évben több ilyen tőkével rendelkeznek a szerkezetváltó 
gimnáziumok diákjai, ám a különbségek nem annyira szembetünőek, mint más dimenziók alapján.

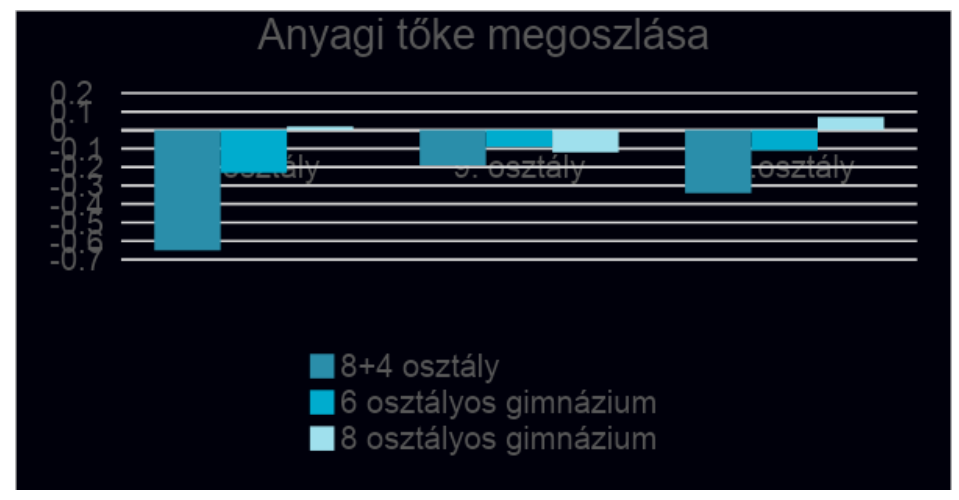

A kulturális tőke bizonyult a legkevésbé arányosan elosztottnak iskolatípusok között: a szerkezetváltó gimnáziumok tanulói lényegesen magasabb kulturális tőkével rendelkeznek, mint bármelyik másik program diákjai. Az általános iskola átlaga negatív irányba rendkívüli módon kitünik. A 4 osztályos gimnáziumok diákjainak kulturális tőkéje önmagában nem tekinthető alacsonynak, ám a szerkezetváltó programok értékeitől egyértelműen elmarad. Érdekes megfigyelni, hogy a kulturális tőke minden vizsgált osztályban a 6 évfolyamos programok esetében a legmagasabb.

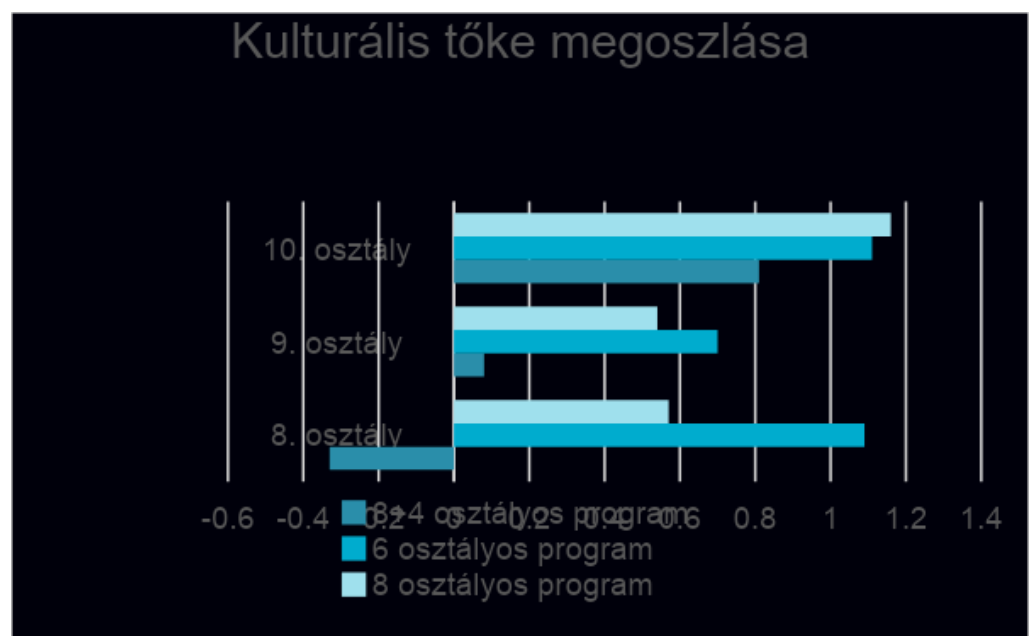

Összegezve tehát elmondható, hogy a humán tőke és a kulturális tőke kirívóan magas különbségeket mutat a programok között, ahhoz képest, amekkora a teljesítmények átlagpontszámának különbsége. Az anyagi tőke tekintetében nem látható komolyabb eltérés. 


\section{Regressziós modellek:}

A fent bemutatott elemzések és az előző fejezetekben kifejtett irodalom alapján feltételezhetem, hogy a szerkezetváltó gimnáziumok diákjai a családi tőkére és egyéb háttérváltozók hatására kontrollálva nem rendelkeznek sokkal jobb képességekkel, mint azok a tanulók, akik 8 év általános iskola után 4-5 évfolyamos gimnáziumokban folytatják tanulmányaikat. Ezen feltételezésemet lineáris regressziós modellekkel vizsgálom meg. Az elemzésben a kis elemszámokból fakadó torzítások lehetőségének kizárása érdekében csak a 9. osztályok eredményeit veszem figyelembe. $(N=1929)$

A regressziós elemzésem során először csak az iskolatípust vontam be magyarázó változóként, majd lépésenként vontam be a családitőke komponenseit mérő változókat, és az egyéb háttérváltozókat. Egyéb háttérváltozók a szubjektív iskolához tartozás érzete ${ }^{19}$ és az iskola munkaerőhiánya ${ }^{20}$. Ezeket bár nem elemzem, fontosnak tartom, hogy a modellben kontroll alatt legyenek a családitőke komponensei hatásának jobb mérése érdekében.

A 2. és 3. táblázatban látható a pusztán az iskolatípussal, mint háttérváltozókkal készült modellek eredménye. Látható, hogy a programtípusok közt matematika esetében 17,9 pont (4 és 6 osztályos program), és 36,8 pont (4 és 8 osztályos program) különbség van. A szerkezetváltó programok tehát kontrollálás nélkül valóban magasabb átlagpontszámot produkálnak, mint a tradicionális, 4 osztályos programok.

2. táblázat: Matematika első modell (csak iskolatípusra kontrollálva)

\begin{tabular}{|l|c|c|r|}
\hline & \multicolumn{1}{|c|}{ Becslés } & SH $^{\mathbf{2 1}}$ & \multicolumn{1}{c|}{ t-érték } \\
\hline (Tengelymetszet) $^{22}$ & 524,926301 & 4,08767002 & 128,417 \\
\hline $\begin{array}{l}\text { ISKTIP: 6 osztályos } \\
\text { gimnázium }\end{array}$ & 17,9381704 & 10,3159529 & 1,738877 \\
\hline $\begin{array}{l}\text { ISKTIP: } 8 \text { osztályos } \\
\text { gimnázium }\end{array}$ & 36,8264212 & 16,3994951 & 2,245583 \\
\hline ISKTIP: Szakközépiskola ${ }^{23}$ & $-55,619479$ & 6,05412991 & $-9,187031$ \\
\hline ISKTIP: Szakiskola & $-134,71138$ & 6,96613701 & $-19,338032$ \\
\hline R-squared & 0,3243541 & 0,02424637 & 13,377429 \\
\hline
\end{tabular}

A szövegértés pontszámok esetében is hasonló számokat figyelhetünk meg: a 4 és 6 osztályos program közt 23,6, míg a 4 és 8 osztályos közt 32,7 pontkülönbség látható.

\footnotetext{
${ }^{19}$ A diákok szubjektív iskolához tartozás (STfac) érzetének mérésére létrehozott változó magas értékei azt jelzik, hogy a diák nem érzi magát az iskolába tartozónak, míg alacsony értékei az iskolához tartozás érzését indikálják. 20 A változót egyes iskolák erőforráshiányának proxyjaként használom. Az, hogy egyes iskolák milyen erőforrásokhoz férnek hozzá, intézményenként változik, és részben független az iskolák típusaitól és egyéb jellemzőitől, viszont a pedagógiai sikerességet erősen befolyásolja. Ezért úgy gondolom, hogy ez egy olyan hatás, amire mindenképpen kontrollálni kell.

21 A becslés standard hibája.

22 A viszonyítási kategória $=4$ osztályos gimnázium.

${ }^{23}$ A modellekben látható, hogy bevontam a szakközépiskolákat és szakiskolákat is. Ennek oka, hogy a PISA adatbázisban az iskolatípust mérő változónak ezek is kategóriái. Ezeket az értékeket azonban -bár tanulságosak jelen dolgozatban nem elemzem.
} 
3. táblázat: Szövegértés/olvasás első modell (csak iskolatípusra kontrollálva)

\begin{tabular}{|c|r|r|r|}
\hline & \multicolumn{1}{|c|}{ Becslés } & \multicolumn{1}{c|}{ SH } & \multicolumn{1}{c|}{ t-érték } \\
\hline (Tengelymetszet) & 522,391289 & 4,17600015 & 125,0937 \\
\hline ISKTIP: 6 osztályos gimnázium & 23,6591626 & 8,22485738 & 2,876544 \\
\hline ISKTIP: 8 osztályos gimnázium & 32,7852359 & 13,9768273 & 2,345685 \\
\hline ISKTIP: Szakközépiskola & $-60,564445$ & 6,54860144 & $-9,248455$ \\
\hline ISKTIP: Szakiskola & $-153,57921$ & 6,29709217 & $-24,38891$ \\
\hline R-squared & 0,3839178 & 0,02131527 & 18,011402 \\
\hline
\end{tabular}

4. táblázat: Matematika eredményekre vonatkozó (végső) lineáris regressziós modell ${ }^{24}$

\begin{tabular}{|l|c|c|c|}
\hline & Becslés & SH & \multicolumn{1}{c|}{ t-érték } \\
\hline (Tengelymetszet) & 481,974065 & 7,88622757 & 61,115922 \\
\hline & & & \\
\hline ISKTIP: 6 osztályos gimnázium & 5,8363412 & 9,28091794 & 0,6288539 \\
\hline ISKTIP: 8 osztályos gimnázium & 26,7297741 & 11,8107483 & 2,2631736 \\
\hline ISKTIP: Szakközépiskola & $-39,694858$ & 5,91401403 & - \\
& & & 6,7119992 \\
\hline ISKTIP: Szakiskola & $-102,79959$ & 8,13236741 & - \\
& & & 12,640795 \\
\hline HISCED_3KATKOZEP & 34,1805699 & 7,24265315 & 4,7193438 \\
\hline HISCED_3KATFELSO & 44,7506628 & 7,47854332 & 5,9838742 \\
\hline Anyagi tőke & $-0,9797702$ & 2,08862904 & - \\
& & & 0,4690973 \\
\hline Kulturális tőke & 15,3316798 & 2,08718596 & 7,3456224 \\
\hline Szubj. Isk-hoz tartozás & $-10,895083$ & 1,49104527 & - \\
\hline Isk.bel.munkaerőhiány & & & 7,3070101 \\
\hline R-squared & $-6,6819984$ & 3,88872567 & - \\
\hline
\end{tabular}

Függö változó: matematika eredmény, független változó: iskolatipus, szülök legmagasabb iskolai végzettsége (humán töke), kulturális töke, anyagi töke, iskolán belüli munkaeröhiány, szubjektív iskolához tartozás-érzet.

\footnotetext{
${ }^{24} \mathrm{Az}$ iskolakategóriák nevei mellett a becslés oszlopban a modell által becsült átlagos pontszámkülönbségek léthatók. A SH oszlopban pedig ezeknek a becsléseknek a hibái láthatóak. Amennyiben a hiba oszlopban látható érték nagyobb, min a becslés oszlopban látható érték, nem állíthatjuk, hogy a modell szerint van statisztikailag kimutatható különbség a két iskolatípus pontszámai közt. Tehát pl.: modell szerint a háttérváltozók bevonásával a 4 és 6 osztályos programok közt átlagosan 5,8 pont a különbség, melynek hibája 9,2. tehát a két csoport közt nem állítható, hogy van statisztikai különbség.
} 
A végsőnek tekintett modellben a három gimnáziumi program diákjainak átlagpontszáma közti különbség látványosan lecsökken (4. táblázat). A négy- és hatosztályos programok esetében az alacsony különbségek mellett a hibák nagy mérete miatt (a becslési hibák magasabbak, mint a különbségek) nem mondható ki, hogy a két csoport átlagpontszámai különböznek. Ebből következik, hogy okkal feltételezhetjük, hogy ha a Wong-féle családitőke-elmélet komponenseire; az iskolák ellátottságára és (az ezzel feltehetően összefüggő) a gyerekek szubjektív tartozás érzésére kontrollálunk, a négy- és hatosztályos programban tanuló diákok valós, képességekkel magyarázható különbsége nagyon alacsony, vagy nem létezik. A négy-és nyolcosztályos gimnázium átlagpontjainak különbsége kicsit magasabb, ám így is alacsony marad.

5. táblázat: Olvasás/szövegértés eredményekre vonatkozó (végső) lineáris regressziós modell

\begin{tabular}{|l|r|r|r|}
\hline & \multicolumn{1}{c|}{ Becslés } & \multicolumn{1}{c|}{ SH } & \multicolumn{1}{c|}{ t-érték } \\
\hline (Tengelymetszet) & 482,314483 & 7,55156559 & 63,869469 \\
\hline ISKTIP: 6 osztályos gimnázium & 12,2920855 & 7,81185716 & 1,573516 \\
\hline ISKTIP: 8 osztályos gimnázium & 22,4152158 & 10,1704384 & 2,203958 \\
\hline ISKTIP: Szakközépiskola & $-43,404622$ & 6,0820232 & $-7,136543$ \\
\hline ISKTIP: Szakiskola & $-117,35269$ & 6,86533684 & - \\
& & & 17,093508 \\
\hline HISCED_3KATKOZEP & 36,3412484 & 6,68441656 & 5,436712 \\
\hline HISCED_3KATFELSO & 35,7666846 & 7,44445909 & 4,804471 \\
\hline Anyagi tőke & 2,0269599 & 1,99430296 & 1,016375 \\
\hline Kulturális tőke & 21,6515502 & 1,97211452 & 10,97885 \\
\hline Szubj. Isk-hoz tartozás & $-13,375355$ & 1,6361014 & $-8,175138$ \\
\hline Isk.bel.munkaerőhiány & $-4,4293109$ & 3,74580142 & $-1,182473$ \\
\hline R-squared & 0,4445635 & 0,01802954 & 24,657506 \\
\hline
\end{tabular}

Függő változó: olvasás/szövegértés eredmény, független változó: iskolatipus, szülők legmagasabb iskolai végzettsége (humán töke), kulturális tőke, anyagi tőke, iskolán belüli munkaerőhiány, szubjektiv iskolához tartozás-érzet.

Az olvasás átlagpontszámok esetében a pontkülönbségek kicsit magasabbak, a becslési hibák azonban szintén aránylag magasak, ezért megállapítható, hogy a különbség, ha nem is 0 , de viszonylag alacsony (5. táblázat). A különbségek mély társadalmi okáról pusztán a modellek alapján nem lehet következtetéseket tenni. Ugyanakkor az én feltételezésem az, hogy az alacsonyabb különbség a matematika pontszámok esetében valószínüleg összefüggésbe hozható a kulturális tőkével. Feltételezhető, hogy a szerkezetváltó programok nagyon magas kulturális tőkével rendelkező diákjai szocializációjuk során több olyan ingernek voltak kitéve, melyek következtében az olvasás- és szövegértés készség fejlődhet.

Tehát a PISA adatokon végzett elemzésem eredményei egybevágnak a szakirodalomnak azon feltevéseivel, melyek szerint a szerkezetváltó gimnáziumok nem képességek, hanem sokkal 
inkább családi háttér alapján szelektálnak. Elemzésem a létező szakirodalmat egyrészt tehát alátámasztja, másrészt azzal az újdonsággal is kiegészíti, hogy rámutat: a kulturális és humán tőke sokkal nagyobb súllyal szerepel a szelekció során, mint az anyagi tőke.

\section{Összefoglalás}

A diákok különbözö tulajdonságaik alapján történö differenciálásának problémaköre nagy hagyományokra tekint vissza a nyugati oktatási rendszerekben. Ma a jogszabályok, oktatásszervezési elvek arra mutatnak, hogy a diákok differenciálása más alapján, mint a tiszta képességeik, nem elfogadható. Az intézményes elvek azonban sokszor nem valósulnak meg maradéktalanul a gyakorlatban. Számos empirikus kutatás mutat rá, hogy adott oktatásszervezési gyakorlatok, melyeknek deklarált céljai közt nem szerepel az egyenlőtlenségek előidézése, mégis kirekesztéshez vezethet. Ilyen gyakorlatnak tekinthető egyes irányzatok szerint a szerkezetváltó gimnázium intézménye is. Ez az intézmény, a mellette érvelők narratívája szerint a legjobb képességü diákok legjobb fejlesztését szolgálja. A valóságban bár nem is gyakran megkérdőjelezett, ám nem is bizonyított tény az, hogy ezt a funkciót képes is betölteni. A szerkezetváltó programok a legjobb képességü diákok kiszürésére szigorú felvételi folyamatokat tartanak végre. Ezek azonban egyáltalán nem bizonyítottan képességek, mintsem családi háttér alapján szelektálják a gyermekeket. Ennek eredményeképpen elképzelhető, hogy a jobb és hátrányosabb helyzetű gyerekek egészen korán, a 4. vagy 6. év után külön intézményekben tanulnak tovább, tehát korai szelekciónak esnek alá, ezzel tovább mélyítve a meglévő (oktatási) egyenlőtlenségeket.

A társadalmi egyenlőtlenségek vizsgálatának végtelen szakirodalma van. Ebből én egy adott irányt, a tőkeelméleteket használtam fel elemzésem során. Érvelésem keretét Wong 1998-as családitőke-elmélete adja.

Kutatásomban a PISA 2015-ös hullámának adataira támaszkodva arra kerestem a választ, hogy a szerkezetváltó gimnáziumok tanulmányi hozzáadott értéke akkor is kimutatható-e, ha kontrollálunk a családi tőkére, és a diákok teljesítményét potenciálisan befolyásoló egyéb változókra.

Elemzésem során arra a megállapításra jutottam, hogy a 4 és 6 évfolyamos programok diákjainak átlagpontszámai nem különböznek egyértelmüen, ha a családi tőke és az iskola egyes dimenziók alapján való ellátottságára kontrollálunk; illetve a különbség a 4 és 8 évfolyamos diákok között is nagyon kicsi. Tehát általánosságban elmondható, hogy a hasonló képességü diákok közül a jobb hátterüek tömörülnek a szerkezetváltó gimnáziumokba. Ezek alapján okkal feltételezhetjük, hogy a szerkezetváltó gimnáziumok nem a valós képességek, mintsem a családi háttér alapján szelektálnak.

Elemzésem eredményei a létező szakirodalom ilyenfajta szelekciót ellenző irányzatával egybevág, ahhoz kiegészítésként szolgálhat azon megállapítása, mely szerint az anyagi tőkének sokkal kevesebb szerepe van a szelekció során, mint a kulturális és a humán tőkének. 


\section{Irodalom}

Balogh, L. (2001). Az iskolai szerkezetváltás története. Új pedagógiai szemle 51(3), 13-30.

Balogh, L. (1991). Szerkezetváltás a középiskolában. Iskolakultúra, 1(9), 57-61.

Bourdieu, P. (1978). Az iskolai kiválóság és a francia oktatási rendszer értékei In: Huszár, T \& Berend, T. I. \& Pataki, F \& Kulcsár, K. (szerk.), A tárdsadalmi egyenlötlenségek újratermelödése Budapest, Gondolat Könyvkiadó. 71-105.

Bourdieu, Pierre (1999). Gazdasági tőke, kulturális tőke, társadalmi tőke In: Angelusz Róbert (szerk.): A társadalmi rétegzödés komponensei. Budapest, Új Mandátum 156-177.

Caro, D. H., \& Biecek, P. (2017). Intsvy: An R package for analyzing international large-scale assessment data. Journal of Statistical Software, 81(7), 1-44.

Coleman, J. S. (1988). Social Capital in the Creation of Human Capital. American Journal of Sociology, (94), 95-120.

Csapó B., \& Molnár Gy., \& Kinyó L. (2009): A magyar oktatási rendszer szelektivitása a nemzetközi összehasonlító vizsgálatok eredményeinek tükrében. Iskolakultúra 2009/3-4

Csapó, B. (2003). Az iskolai osztályok közötti különbségek és az oktatási rendszer demokratizálása. Iskolakultúra, 13 (8) 107-117)

Gamoran, A. (2009). Tracking and Inequality: New Directions for research and practice. In: Apple, Ball et al (szerk.): The Routledge International Handbook of Sociology. 213-229.

Jozsa, K. \& Badó, Zs. (2017). A gimnáziumi felvételi vizsga eredményének és a gimnáziumi tanulás sikerességének kapcsolata. Új Pedagógiai Szemle. 67. 39-54.

Kerckhoff, A.C. (1986). Effect of Ability Grouping in British Secondary Schools. American Sociological Review, 51(6), 842-858.

Kulik, J. A., \& Kulik, C.-L. C. (1992). Meta-analytic Findings on Grouping Programs. Gifted Child Quarterly, 36(2), 73-77.

Liskó, I. (1993). Szerkezetváltó iskolák. Kutatás Közben 190. Oktatáskutató Intézet, Budapest. Loveless, T. (1998). The Tracking and Ability Grouping Debate. The Thomas B. Fordham Foundation. (2)8 5-36.

OECD (2010). PISA 2009 Results: Overcoming Social Background - Equity in Learning Opportunities and Outcomes (Volume II): Equity in learning opportunities and outcomes. OECD Publishing.

OECD (2016). PISA 2015 Results (Volume I) Excellence and Equity in Education, PISA: excellence and equity in education. OECD Publishing.

OECD (2017). PISA 2015 Technical Report. OECD Publishing.

Oktatási Hivatal (2015). PISA Összefoglaló jelentés 2015

Pusztai, G. (2009). A társadalmi tőke és az iskolai pályafutás. Budapest: Új Mandátum Kiadó. 10-174.

Radó Péter (2005). Méltányosság az oktatásban: dimenziók, okok és oktatáspolitikai válaszok. OECD analitikus országjelentés - Magyarország.

Radó Péter (2007). Oktatási egyenlőtlenségek Magyarországon. Esély 1(4), 24-36.

Radó, P. (2018). A közoktatás szelektivitása mint a roma szegregáció általános kontextusa. Én vétkem: helyzetkép a magyar oktatási szegregációról. 31-57.

Slavin, R. E (1987). Ability grouping and Student Achivement in Elementary Schools: A BestEvidence Synthesis. Review of Educational Research, 57 (3) 293-336. 
Slavin, R.E (1990). Achivement Effects of Ability Grouping in Secondary Schools: A BestEvidence Synthesis. Review of Educational Research 60 (3) 471-499.

Strakova, J. (2012). Early Tracking in the Czech Education System In: Daniel Pop (szerk.) Education Policy and Equal Education Opportunities. Open Society Foundations, New York. 181-206.

Wong, R. S. (1998). Multidimensional influences of family environment in education: the case of socialist czechoslovakia. Sociology of Education, 71 (1), 1-22. 